\section{HIV knowledge and related sexual practices among Portuguese men who have sex with men}

\author{
Conhecimento e práticas sexuais associadas ao HIV \\ entre homens portugueses que fazem sexo \\ com homens
}

\author{
Conocimiento y prácticas sexuales relativas al VIH \\ entre hombres portugueses que tienen sexo \\ con hombres
}

\begin{abstract}
1 Unidade de Investigação em Psicologia e Saúde, Instituto Universitário de Ciências Psicológicas, Sociais e da Vida, Lisboa, Portugal.

2 HIV Center for Clinical and Behavioral Studies, Columbia University/New York State Psychiatric Institute, New York, U.S.A.

Correspondence

N. Nodin

Unidade de Investigação em Psicologia e Saúde, Instituto Universitário de Ciências Psicológicas, Sociais e da Vida.

Rua Jardim do Tabaco 34 Lisboa 1149-041, Portugal. nunonodin@gmail.com
\end{abstract}

\begin{abstract}
Qualitative studies of the sexual risk practices of Portuguese men who have sex with men (MSM) are scarce, as have been campaigns to target this group despite high HIV infection rates. This study investigates the concepts and practices of safer sex of a group of 36 Portuguese self-identified gay men (age: $\bar{x}=34.4, S D=9.1$ ) who have met sexual partners online; two identified as HIV positive. Thematic analysis of interviews showed that our participants were aware of HIV transmission risks and tended to protect themselves in most sexual practices. Oral sex and steady relationships, however, did not always include safer practices. Participants tended to rely on indirect sources of information when assessing their partners' HIV status, such as their physical characteristics or the information available in online profiles. Contrasting HIV positive and negative men's sexual expectations and practices indicated that communication shortcomings might be putting some at risk. Findings suggest that safe sex is a relational practice which can only be understood and addressed within the context in which it occurs.
\end{abstract}

Safe Sex; Sexual Behavior; HIV
Nuno Nodin 1

Isabel Pereira Leal 1

Alex Carballo-Diéguez ${ }^{2}$

\section{Resumo}

São escassos os estudos qualitativos sobre as práticas sexuais de risco de homens portugueses que fazem sexo com homens (HSH), assim como têm sido as campanhas dirigidas a este grupo, apesar das elevadas taxas de infecção por HIV entre HSH em Portugal. Este estudo investiga os conceitos e práticas de sexo seguro de um grupo de 36 HSH portugueses que encontraram parceiros sexuais na Internet (idade: $\bar{x}=34,4, D P=9,1$ ). A análise temática das entrevistas mostrou que os participantes estavam cientes dos riscos de transmissão do HIV e tendiam a se proteger na maioria das práticas sexuais. Porém, sexo oral e relacionamentos estáveis nem sempre incluíam práticas seguras. Os entrevistados tendiam a confiar em fontes indiretas de informação para avaliar o estatuto HIV de seus parceiros, como o seu aspecto físico ou as informações disponíveis em perfis online. Verificaram-se ainda falhas de comunicação que podem estar colocando alguns em risco. Os resultados sugerem que o sexo seguro é uma prática relacional que deverá ser entendida e prevenida em função dos contextos em que ocorre.

Sexo Seguro; Comportamento Sexual; HIV 


\section{Introduction}

In January 2010 the first public, large-scale multimedia campaign aiming to promote condom use among gay men in Portugal was launched in response to government policies aimed at developing more effective HIV prevention strategies 1. Until then, and despite community-based efforts 2 , most HIV-prevention messages targeted the general population. Some of these messages may actually have induced risk behaviors as a result of factors such as: the vagueness of their goals; a lack of clear messaging; the frequent use of fear as a prevention strategy and language that might be misunderstood by the target audience 3 . It has also been suggested that the creators of these messages were unclear about their target audience and contexts in which unsafe sex occurs, resulting in ambiguous messages 4. Historically, this may have led to the Portuguese having some of the most inaccurate information about HIV in Europe according to a 2003 survey, including almost one-third of respondents that believed that HIV could be transmitted through kissing, mosquito bites or by using public bathrooms 5 .

Data about the general population and about men who have sex with men (MSM) over the last decade shows a grim picture overall regarding HIV in Portugal within the larger European context. A projection study published in 2005 suggested that there was "an apparent change in the decreasing [HIV infection] tendency in the Homo/ Bisexual category" 6 (p. 140) in this country. Epidemiological data about HIV infection in Portugal indeed showed that since 2003 the number of new infections in that category increased, peaking in 2009, and only since then has there been a steady decrease in the rate 7 .

Around 2.3 million people were living with HIV in Europe at the end of 2006, of which around $50 \%$ had not been diagnosed. Portugal ranked second in terms of the number of people living with HIV after Estonia. Heterosexual intercourse had become the predominant mode of transmission in most countries, including Portugal 8 .

More recent reports show that the number of people living with HIV in Europe continues to increase and that HIV is concentrated in key populations at higher risk of infection such as MSM. This is particularly the case in Western Europe, where infection rates for MSM increased by $6 \%$ between 2006 and 20127 . There has also been a disproportional concentration of sexually transmitted infections (STI) among HIV-positive MSM in the same region since $1996{ }^{9}$.

Portugal no longer holds a high position in the European ranking for HIV prevalence in the general population 7 . This may be linked with fear of HIV infection and increased knowledge about viral transmission, even if condom use seems to be dependent on life and relationship contexts among heterosexuals 10 . The relevance of social networks has also been highlighted for this population, in that these may influence greater sexual experimentation as well as condom use 11 .

On a recent study with Portuguese MSM, only a minority of participants mentioned having been the target of prevention campaigns, leading the authors to suggest the need for functional and effective prevention strategies directed at this population 12. Despite limited targeting of safe sex messages, this group was reported to have safer sexual behaviors and higher risk awareness compared with the heterosexual population 13 . However, only $28 \%$ reported always using a condom during anal intercourse in the previous year; $39 \%$ had never tested for HIV and $40 \%$ reported not using a condom when falling in love.

Unsafe sexual practices among MSM have been on the rise in several European countries 14,15,16,17 but the related contexts and associated factors remain largely understudied in Portugal. The Internet has become a popular way for MSM to meet sexual partners throughout the continent, which in turn has been associated with risk behaviors $18,19,20$. A Portuguese study has suggested that using online sexual networking websites has influenced MSM's sense of selves and their sexuality in various ways, for instance by making them more accepting of their sexual orientation; by increasing their sexual experimentation; and by allowing them to be more sexually assertive 21 .

Growing awareness of the need to target MSM's needs for HIV prevention in the country has led to the development of community-based initiatives 22 and research projects 12,13,23. However, in Portugal there is still a surprising lack of qualitative and ethnographic studies about this reality which might allow for a better understanding of MSM's HIV-related knowledge and behaviors, particularly of those who use technology to interact and engage with new sexual partners. The current study aims to address some of the gaps in knowledge and to shed light on the needs for HIV prevention, through analyses of safe sex concepts and practices among a group of Portuguese MSM who use the Internet to meet sexual partners.

\section{Methods}

\section{Participant recruitment}

This study was approved by an ethics evaluation process conducted by the Scientific Committee 
of the Instituto Universitário de Ciências Psicológicas, Sociais e da Vida, Lisbon, Portugal.

Participants were recruited online and through other methods, such as word of mouth. Online recruitment was via an Internet-based profile in a popular website used by Portuguese MSM to find sexual and other partners. Individuals actively responded to the profile or were recruited by sending eight messages daily (the limit set to non-paying members of the website) inviting members who were online to participate in the research.

Volunteers were contacted by telephone and screened for eligibility: volunteers had to be male, aged 18 years or older, Portuguese or living in Portugal for at least one full year, fluent Portuguese speakers and to have had at least one sexual contact with another man whom they had met online. Recruitment continued until no significantly new topics were coming up in the interviews.

\section{Measures}

A semi-structured interview guide was used to ask participants about their Internet use, meeting partners online for sex, and safe sex. The guide was specifically designed for this study, being based on that developed by Carballo-Diéguez et al. 24, but amended after initial assessment of validity for Portuguese-speaking interviewees. For the assessment, three volunteers were interviewed using a translation and adaptation of the initial guide, thus informing changes, eliminating unclear questions and including relevant others that were missing.

\section{Data collection}

Participants were scheduled for face-to-face interviews, at the beginning of which informed consent was obtained. Interviews were audiorecorded with participants' permission. After the interview, participants were asked to complete a written questionnaire covering demographics, sexual health and behavior.

\section{Data analysis}

The audio-recorded interviews were transcribed, cleaned of transcription errors and any information that might identify the subject and coded for analysis. Our analysis followed the procedures described by Braun \& Clarke 25. We used an inductive and semantic approach to analyze the data, informed by our research questions.

Initial coding paralleled the structure of the interview guide to capture the major themes cov- ered by the interview. For this study, first level code "safe sex" was used. It covered questions and answers on the definitions and practices of condom use and safe sex. The main questions asked during the interview about safe sex were used to create second level codes. Then, a thorough reading of the material under each code was undertaken to identify secondary themes. Analytical bias was minimized by clear and consensual previous discussion and definition of categories by co-authors and by using transparent documentation (NVivo 8.0. QSR International; http://www.qsrinternational.com).

Results were organized according to relevant categories identified: Definitions and Practices of Safe Sex; Risk Reduction; and Relationships and Risk. Quotations were translated from the Portuguese originals, maintaining the meaning and nuances of the participants' testimonies, using equivalent idiomatic expressions when appropriate.

\section{Results}

36 participants, between the ages of 18 and 62 $(\bar{x}=34.4 ; \mathrm{sd}=9.1)$ were recruited and interviewed. Most of the men volunteered online, five (13.9\%) were actively invited via the web-based profile, and $10(27.8 \%)$ via other means.

Most participants self-identified as white (91.4\%), and gay (94.4\%). The large majority had at least 11 years of education (97.2\%), of which about half $(51.4 \%$ ) had completed a degree in higher education. Most were working (77.8\%) and had never been married (83.3\%). 13 (36.1\%) reported being in an on-going relationship, one of which was with a woman. 33 (91.7\%) had tested for HIV, of which two (5.6\%) were HIVpositive.

Most of the participants lived in the Lisbon metropolitan area; three were non-Lisbon residents; and two were non-Portuguese living in Portugal (for a minimum of 4 years). The average length of interview was $1 \mathrm{~h} 30 \mathrm{~m}$.

\section{Definition and practices of safe sex}

The majority of participants correctly defined safe sex as the use of a condom during anal intercourse. Several also included in their definitions condom use during oral sex, although many argued that not using it in this activity is less risky than during anal sex or admitted to being unsure about its risk.

"Safe sex for me is, for gay men, to put on a condom from the moment when there is an erection" (n34, age 31 years, single). 
"From what I've read [safe sex] is everything that has to do with the contact between the anal mucosa and the other person's penis because even before the ejaculation there are those secretions that may cause infection. Contact between mouth and penis may also imply risks, although they are minor because the saliva destroys the virus... But if the person has a wound and there is contact, it [infection] may happen" (n31, age 41, single).

All of the participants said they used condoms with their non-steady partners for anal intercourse. During oral sex, however, most said they did not use them, despite their knowledge of the risks involved.

"My application of safe sex has been to never have anal sex without a condom. (...) I know that through oral sex you can also get AIDS and other illnesses, but in oral sex I never use a condom" (n20, age 27, single).

A few of the interviewees mentioned the possibility of HIV infection through kissing, revealing accurate knowledge about the physiology of disease transmission along with a high level of infection anxiety.

"Although we know that chances of transmission of certain diseases through kissing or though contact with secretions [is low], it cannot be neglected, because some people have cavities or wounds in their gums with blood. Of course the chance is low, but it happens" (n50, age 43, single).

\section{Risk reduction}

Participants did not limit their safe sex strategies to using condoms for anal intercourse. A variety of risk reduction practices were identified during the interviews. We grouped these into three sub-categories: (i) oral sex; (ii) evaluation of the partner; and (iii) other risk reduction strategies.

\section{- Oral sex}

Following the awareness shown by many of the interviewees about oral sex related infection risk, and despite their reluctance to use condoms in that practice, many said they used other ways to minimize their risk of infection through fellatio. The most common was avoiding ejaculation in the mouth or swallowing semen.

"Through my experience I started to notice that if the person on whom I was performing oral sex was dripping semen, that he was about to come... [So] when that happened I would spit out or whatever, or I would just stop doing oral [sex]" (n28, age 22, single).

" $[\mathrm{N}]$ ot swallowing sperm during oral sex. That is what safe sex is for me" (n55, age 18, in a relationship).
A few of the interviewees also limited the practice of oral sex as a way to reduce their risk.

"For me to practice oral sex, it will have to be within a relationship in which I know the person is well; and to let someone do it on me I also have to know that person quite well" (n16, age 29, single).

\section{- Evaluation of the partner}

Several of the participants mentioned that they would evaluate their potential sex partners in order to assess their risk by having sex with them. Although they focused on different aspects of the partner and situation, the most common was an assessment of the appearance of the potential partner.

"For me the hygiene [of the guy] is also very important and I associate that a little as well to the issue of safe sex" (n9, age 35, single).

"If the person appears with infected pimples or with many skin spots, and so on and so forth, I stop. I stop everything!" (n19, age 45 , single).

"There was this guy with whom I spoke through [the website] that had this really nice pics and I went to meet him (...) I could tell that he was the same guy from the pictures, but he looked really bad and I got the feeling that he had AIDS" (n20, age 27, single).

Another method used to assess a potential sex partner's risk was to screen the information available in their online profiles.

"I look at a profile, because I'm very careful about health issues, and if the person says [in his profile] 'sex, sex, sex', I just avoid that guy [because] if he is someone so interested in sex, then the probability of him having a disease is very high" (n16, age 29 , single).

"If someone says [in his profile] that he is not interested [in safe sex], I will not contact him; if he says '[safe sex] needs to be discussed'... I really don't know what that means, but I don't want to be in a position in which a person will want to penetrate me or have an orgasm in my mouth without protection" (n17, age 62, in a relationship).

Other men extended this screening to the interaction established online before an encounter

"Usually people start by saying in their profiles if they like safe sex or not. Those who do not like it, when I chat with them through IM [instant messaging], I will say: 'I saw in your profile that you don't like safe sex. I'm pro safe sex; if we meet, how's it going to be?"' (n42, age 30, in a relationship).

Discussing safe sex or condom use prior to a face-to-face encounter was not common. However, safe sex was a standard procedure and expected to happen by default in the sexual encounters of these men. 
"I always have safe sex; for me it's taken for granted. It is not actually something that is discussed. When [we] start to have sex I will go get condoms" (n6, age 29, single).

"I never had to converse or discuss if we will have safe sex or not. I mean everyone with whom I've been assumes that sex is supposed to be safe" (n38, age 45, in a relationship).

When asked, the men said that the safe sex considerations and procedures they followed with their partners met online were the same as those with partners whom they met offline.

"In the casual [sexual] relationships I had, regardless of the fact that they came from the Internet or not, I will obviously use a condom, so I don't distinguish things that way, it has to do with the other person and myself, not with the relationship and not with where I met him" (n33, age 33, single).

\section{- Other risk reduction strategies}

Another risk reduction strategy used was reducing the number of sexual partners. One participant said that during six years at the onset of the AIDS crisis he had no sexual contact with men due to his concern about infecting his wife. Other participants also reported limiting the number of partners in order to reduce their risk.

"The fact that I met these guys and already was having sex with them was a little promiscuous of me and I could have got myself infected" (n18, age 29, single).

With the same goal in mind, some participants limited the types of activities in a sexual encounter.

“But I don't have many risk situations, no, no, no... I don't [anally] penetrate nor am I penetrated with people I meet at night" (n11, age 41, single).

"In order to have [an absolutely] safe attitude, there is only [one possible attitude], that is not to kiss anyone" (n50, age 43, single).

Other strategies mentioned by participants were showing or asking for their partners' HIV test results, avoiding ejaculation during intercourse (even when using a condom), and limiting drug or alcohol use during sexual encounters.

\section{Relationships and risk}

Safer sex behaviors within steady relationships differed from those in casual encounters. Most men would consider stopping using condoms when in a relationship. In fact, some of those who had been in relationships mentioned that they had stopped using condoms at some point.

"[I always use condoms,] unless I would start a relationship with someone and at some point we would decide we didn't want to use condoms anymore between the two of us" (n43, age 31, single).

The issue of trust was commonly mentioned in this context. Definitions of trust, however, varied.

"All the relationships I had in the past were with persons with whom I would have safe sex with and then I think it continues to be safe [even without condoms] from the moment I trust. It is a question of definition, but initially we always use condoms and then we stop using them at some point" (n22, age 36, single).

"There were only one or two situations in which [using a condom] did not happen, due to matters of trust, that is. He was my boyfriend, I trusted him and we did not use one. Although I always go for the quick HIV test afterwards" (n55, age 18 , in a relationship).

These narratives show that trust is used as a justification not to use condoms, even in situations in which it may be important to use them. The younger of these two men (n55), for instance, also mentioned that none of his relationships had lasted for more than one month.

However, within the context of longer relationships, and before condom-use ceased, commonly both partners would test for HIV and other sexually transmitted infections.

"Initially we used condoms. In the meanwhile we both tested. Everything was okay. And now we do it without a condom" (n8, age 49, bisexual, in a relationship).

Regardless of HIV-testing and negative results, some participants said that they regretted having taken chances, considering the risks involved in stopping condom use even within relationships.

"[He] was the first man that I fell in love with, which was foolish, because we had nothing in common, but [I met him] over the Internet and I was obsessed with the Internet and I had sex without condoms, and that was foolish because he was having sex with other people too" (n10, age 42, in a relationship).

Many participants spoke of agreed or nonagreed non-monogamy in their relationships and in the relationships with men with whom they had sex. However, in none of these there were direct references to sexual risk behaviors.

\section{- Risk reduction by HIV positive men}

Two of the participants knew their HIV-status to be positive. Both admitted to having a very active sex life, one going as far as calling himself a "sex addict" (n32, age 46, single). He tended not to disclose his serostatus to his sexual partners. The other participant (n46, age 36) had a sexu- 
ally open, long-term relationship with another HIV-positive man. He practiced brachioproctic eroticism (known as fisting or fist fucking) and mentioned being careful to look at the hands of the man who would fist him and sometimes asking him to use rubber gloves to minimize the risk of hepatitis $\mathrm{C}$ infection.

Both men indicated that they would only practice anal intercourse with a condom, but did not generally use one for insertive or receptive oral sex. However, they had slightly different attitudes towards ejaculation during oral sex:

"Some practices that people are alerted to, including ejaculation inside the mouth, when the person is aware [of the risks], I think that, and you can call me whatever you like, I... I... I still do it [I ejaculate inside the guy's mouth]. It is a risk that the person is perfectly aware of taking" (n32).

"I usually don't ejaculate in people's mouths if I think they're serodiscordant. Even when they're HIV-positive, I don't like to do it. I mean, I like it as an activity, but... sperm play is something you have to be really careful about, right? Due to drug resistance factors and all that. Both for me and for my partners. Where I take the most risks, perhaps, is with my boyfriend" (n46).

Both would consider ejaculating in a partner's mouth without an open discussion about their own serostatus, although their personal ethics about it differed.

"We are all adults and one way or another, I always bring up the word AIDS or seropositive or something like that. I may not tell people I'm HIVpositive because of the stigma, which would most certainly lead to the end of everything [sexual] that is going on or about to start... but I always bring up the topic, so people know" (n32).

"No, I don't say [I'm HIV-positive]. Sometimes I do, when I understand people are [also positive], then I talk about it freely. But people don't talk much about it here [in Portugal]. They rather... even when it is assumed, even when it is understood and clear, it is not mentioned..." (n46).

This participant also discussed how he often made assumptions about the serostatus of others using the information they included in their online profiles. He interpreted information such as "Discussion needed" or "No" for the safe sex option of the profile as a code for seropositivity.

Some of the HIV-negative participants of this study were asked if they inquired about their sexual partners' HIV status. Most said they did not. Typically they thought that, even if their potential partners were HIV-positive, they would not tell the truth.

\section{Discussion}

The MSM who participated in this research generally had good knowledge of the sexual pathways to HIV infection and of prevention strategies. They also revealed safe behaviors in the majority of their anal sex practices. This suggests that they received accurate HIV-related information and that they are aware of the risks and of how to avoid them, despite the traditional lack of prevention campaigns targeted at MSM in Portugal. Typically, condoms are produced at some moment before intercourse and used for anal sex. Thus, although partners did not discuss safe sex prior to sexual encounters, this did not seem to stand in the way of adequate prevention behaviors.

The significant levels of HIV information we found on our sample may reflect the participants' overall high educational background, which may additionally account for the relative homogeneity of our results. Therefore, further research that might help add texture to this reality is still needed.

Despite the high levels of safe anal sex knowledge and reported behaviors, most men in this study said that they did not use a condom during oral sex. Although oral sex is considered to be a lower risk practice, several studies have shown that it may account for a proportion of HIV in fections 26,27 . Some men reported using alternative strategies to keep safe during fellatio, such as avoiding oral contact when their partner's ejaculate. However, others seem to hold inaccurate beliefs, such as that the risk is minimized by not swallowing semen, which means that they may be at risk from pre-ejaculation fluids or by taking semen in their mouths. These findings are also significant in light of the estimated high percentages of European MSM who are unaware of their HIV status ${ }^{8}$ and who may unknowingly be putting their sexual partners at risk of infection.

Many men tried to assess their partners' HIV status by evaluating their appearance or behavior. Despite showing a concern with infection, these are ineffective prevention strategies. Assuming that their partners are HIV-negative based on appearance may lead some men to be less safe 28 . The analysis of the practices and concerns of the two HIV-positive men in this study along with those of the other men who often do not ask about their partners' serostatus, demonstrated that assumptions and communication shortcomings may be leading HIV-negative men to becoming exposed to HIV, in particular during oral sex.

Risk-reduction strategies were uncommon. Asking for a partner's HIV test result was only oc- 
casionally mentioned in this sample and other strategies that MSM have been shown to use, such as serosorting, strategic positioning, or negotiation of viral load 29,30 were not specifically mentioned by participants in our study. Therefore, our results are suggestive of a lack of HIV and risk related language that might be used to negotiate sexual activity among the MSM in our sample, leaving safety decisions to be made based on what is implicitly but not explicitly communicated. At least one of our participants (n46) believed this to be specific to the Portuguese context.

Men will collect some of this implicit risk information from the profiles of Internet based sites that they use to meet others for sex. This means that these websites and profiles may be relevant in filling in the communication gaps between MSM. Some of these websites do allow users to easily share with other users information about their HIV status; safety of activities sought and other related information, albeit not consistently 31 . Therefore, it may be relevant to work with website managers to develop more transparent and sexual health friendly interfaces for their users, as well as to help men be more clear and assertive in their sexual communication on and offline.

Most interviewees said that the prevention strategies they used with men they met for sex offline or online were the same, which contrasts with European studies that suggest that risk behaviors are greater with men met online 18,19 . For instance, a Spanish study has suggested that a more thorough partner selection processes online, which includes intimate communication with potential partners, may lead to subjective impressions with regard to sexual risk, thus facilitating unprotected sexual activity with these partners ${ }^{32}$. Although a Portuguese study with MSM suggested changes in sexuality associated with meeting partners online, these changes do not seem to be related to the protective behavioral patterns on and offline that we found in the current study 21 . Therefore, links between using the Internet to meet partners and sexual behavior patterns is an issue that would benefit from further analyses within the Portuguese context.

Steady relationships may be contexts where risks are permitted, as couples tend to relax patterns of safety at some point in the relationship. This result supports previous Portuguese MSM sexual behavior reports ${ }^{13}$. In spite of "negotiated safety", in which couples stop using condoms after HIV-testing, risk situations may still occur since many relationships are not sexually closed and the decision to stop condom use within the relationship is mostly based on trust 33 . Howev- er, trust, as some of our participants agreed, is a rather subjective concept, leaving space for various expectations and behaviors. A study showed a $23 \%$ rate of broken agreements on having sex outside of the primary relationship among MSM, with different aspects of the couple's dynamics, including trust, as being the best predictors of agreement maintenance 34 . Further research has also shown that most HIV infections occur from main sex partners 27,33 . This suggests that relationship dynamics in relation to HIV risk practices are relevant and should be considered in the context of prevention efforts.

Our findings suggest that the concepts of safe sex on our sample are highly contextual and therefore in some ways not dissimilar from those found among Portuguese heterosexuals 10,11, but still maintaining their specificity that deserves further inquiry.

\section{Study limitations}

The sample used for this study is not representative of Portuguese MSM. It is possible that men who felt uncomfortable with disclosing unsafe sex refrained from participating. Therefore the results of this study reflect the bias associated with a convenience sample containing highly educated and mostly professional individuals, sensitive to the topic of this study, motivated and willing to disclose private matters to a researcher. All participants had experience of meeting sexual partners online, one of the key areas of focus of our research, and therefore our results may disproportionately reflect those experiences.

Uncontrolled sensitivity to certain topics and unintended bias in the selection of quotes to illustrate the issues being addressed is always a possibility in qualitative analysis. To prevent this, standardized procedures were used as much as possible to provide bias-free results.

\section{Final remarks}

According to the latest European surveillance report, "[f] or the countries in the EU/EEA and in the West, interventions to prevent and control HIV among MSM are the cornerstones of the HIV response" 7 (p. ix). Despite our modest sample size and the limitations identified, we believe our results can contribute to inform the development of more effective health education policies and strategies aimed at promoting safer sex and risk reduction among MSM living in Portugal. Considering that in general, participants in our study were aware of HIV transmission risks and tended to protect themselves in most sexual practices, prevention efforts should do more than just 
provide information and focus on communication and negotiation skills both on and offline. They should also work towards building sustainability of safer practices that will be affected by different life contexts, types of partner and social influences.

\section{Resumen}

Los estudios cualitativos sobre la práctica sexual de riesgo entre hombres portugueses que tienen sexo con hombres (HSH) son escasos, también las campañas preventivas dedicadas a este grupo, a pesar del alto índice de infección de VIH. Este estudio investiga conceptos y prácticas de sexo más seguras de un grupo de $36 \mathrm{HSH}$ portugueses (edad: $\bar{x}=34,4 ; D P=9,1$ ) que hubieran conocido parejas por Internet para mantener relaciones sexuales. El análisis temático de las entrevistas muestra que los participantes eran conscientes de los riesgos de transmisión del VIH y que tendieron a protegerse en la mayoría de las prácticas sexuales. Sin embargo, el sexo oral y las relaciones estables no implicaron prácticas más seguras siempre. Los participantes tendían a confiar en fuentes indirectas de información a la hora de evaluar el estado del VIH de sus parejas (e.g. aspecto físico; información disponible en perfiles de Internet). Una comunicación defectuosa puede poner a algunos en riesgo. Los resultados sugieren que el sexo seguro es una práctica relacional que necesita ser entendida e intervenida dentro de su contexto.

Sexo Seguro; Conducta Sexual; VIH
Changing trends in HIV in Portugal as shown by the infection rates for MSM over the last decade suggest that larger surveys as well as qualitative studies should be conducted to support effective and unbiased national prevention efforts.

\section{Contributors}

N. Nodin contributed to the conception and design, acquisition of data, analysis and interpretation of data, drafting the article, and final approval of the version to be published. I. P. Leal and A. Carballo-Diéguez contributed to the conception, design, analysis and interpretation of data, revising the manuscript critically for important intellectual content, and final approval of the version to be published.

\section{Acknowledgments}

This research was funded by Grant SFRH/BD/ 17396/2004 from the Fundação para a Ciência e Tecnologia, Lisbon, Portugal. 
1. Despacho no 19871/2005. Diário da República 178 15 de Setembro de 2005, Serie II. Lisboa: Imprensa Nacional Casa da Moeda; 2005.

2. ILGA Portugal. Associação ILGA Portugal lança colecção de postais visando aumentar a confiança de HSHs em relação ao sexo e dando dicas para o tornar mais seguro. http://www.ilga-portugal.pt/ glbt/saude20090312.htm (accessed on 03/Feb/ 2010).

3. Cunha-Oliveira A, Cunha-Oliveira J, Pita JR, Cardoso SM. Os jovens universitários e a prevenção do VIH/sida. In: IX VIH/AIDS Virtual Congress 2008. http://www.aidscongress.net/article.php?id_co municacao=353 (accessed on $02 / \mathrm{Feb} / 2010$ ).

4. Lopes OMCMS. As campanhas publicitárias de SIDA (spot), destinadas ao público feminino. In: IV VIH/AIDS Virtual Congress. http://www.aidscon gress.net/article.php?id_comunicacao=185 (accessed on $02 / \mathrm{Feb} / 2010$ ).

5. European Opinion Research Group. Eurobaromètre Spécial. Brussels: European Commission; 2003. (Report 183-2/Vague 58.2).

6. Amaral JA, Pereira EP, Paixão MT. Data and projections of HIV/AIDS cases in Portugal: an unstoppable epidemic? J Appl Stat 2005; 32:127-40.

7. European Centre for Disease Prevention and Control; World Health Organization. HIV/AIDS surveillance in Europe 2012. Stockholm: European Centre for Disease Prevention and Control; 2013.

8. Hamers FF, Phillips AN. Diagnosed and undiagnosed HIV-infected populations in Europe. HIV Med 2008; 9:6-12.

9. Dougan S, Evans BG, Elford J. Sexually transmitted infections in Western Europe among HIV-positive men who have sex with men. Sex Transm Dis 2007; 34:783-90

10. Aboim S. Risco e prevenção do HIV/Aids: uma perspectiva biográfica sobre os comportamentos sexuais em Portugal. Ciênc Saúde Coletiva 2012; 17:99-112.

11. Aboim S. Redes sociais e comportamento sexual: para uma visão relacional da sexualidade, do risco e da prevenção. Saúde Soc 2011; 20:207-24.

12. Dias S, Gama A, Fuertes R, Cohen G, Rosa R, Mendão L, et al. Utilização de serviços de saúde relacionados com a infecção VIH por parte de homens gays: acesso a informação, prevenção e teste. Psicologia 2012; 26:109-28.

13. Aboim S. Homossexualidade e bissexuallidade: práticas, atracção e orientação sexual. In: Cabral MV, Ferreira PM, organizadores. Sexualidades em Portugal: comportamentos e riscos. Lisboa: Bizâncio; 2010. p. 147-200.

14. Harding R, Clucas C, Lampe FC, Norwood S, Leake Date H, Fisher M, et al. Behavioral surveillance study: sexual risk taking behaviour in UK HIV outpatient attendees. AIDS Behav 2012; 16:1708-15.

15. Le Vu S, Velter A, Meyer L, Peytavin G, Guinard J, Pillonel J, et al. Biomarker-based HIV incidence in a community sample of men who have sex with men in Paris, France. PLoS One 2012; 7.
16. Villaamil F, Jociles M. Risk and community: the impact of HIV among gays in Madrid. The case of sex clubs. Sexualities 2011; 14:580-96.

17. Vanden Berghe W, Nostlinger C, Hospers H, Laga M. International mobility, sexual behaviour and HIV-related characteristics of men who have sex with men residing in Belgium. BMC Public Health 2013; 13:968.

18. Adam PC, Murphy DA, de Wit JB. When do online sexual fantasies become reality? The contribution of erotic chatting via the Internet to sexual risktaking in gay and other men who have sex with men. Health Educ Res 2011; 26:506-15.

19. Bolding G, Davis M, Hart G, Sherr L, Elford J. Gay men who look for sex on the Internet: is there more HIV/STI risk with online partners? AIDS 2005; 19:961-8.

20. Fernández-Dávila P, Zaragoza Lorca K. Trust and sexual interaction: the significance of the Internet on the sex life and sexual risk behaviors of gay and bisexual men in Spain. Int J Sex Health 2011; 23:120-38.

21. Nodin N, Carballo-Diéguez A, Leal IMP. Sexual use of the Internet: perceived impact on MSM's views of self and others. New Media \& Society 2013; http://nms.sagepub.com/content/early/2013/06/ 05/1461444813489508.abstract.

22. Campos MJ, Teófilo E, Machado H, Brito J, Esteves J, Mendão L, et al. MSM testing and linkage to care in Lisbon (poster presentation). In: Conference HIV in Europe - Working Together for Optimal Testing and Care. http://www.checkpointlx. com/08-HIVinEurope.pdf (accessed on 09/ Mar/2014).

23. Carvalho C, Fuertes R, Lucas R, Martins A, Campos MJ, Mendão L, et al. HIV testing among Portuguese men who have sex with men: results from the European MSM Internet Survey (EMIS). HIV Med 2013; 14:15-8.

24. Carballo-Diéguez A, Ventuneac A, Bauermeister J, Dowsett GW, Dolezal C, Remien RH. Is 'bareback' a useful construct in primary HIV-prevention? Definitions, identity and research. Cult Health Sex 2009; 11:51-65.

25. Braun V, Clarke V. Using thematic analysis in psychology. Qual Res Psychol 2006; 3:77-101.

26. Richters J, Grulich A, Ellard J, Hendry O, Kippax S. HIV transmission among gay men through oral sex and other uncommon routes: case series of HIV seroconverters, Sydney. AIDS 2003; 17:2269-71.

27. Sullivan PS, Salazar L, Buchbinder S, Sanchez TH. Estimating the proportion of HIV transmissions from main sex partners among men who have sex with men in five US cities. AIDS 2009; 23:1153-62.

28. Bailey A, Hutter I. Cultural heuristics in risk assessment of HIV/AIDS. Cult Health Sex 2006; 8:465-77.

29. Jin F, Prestage GP, Ellard J, Kippax SC, Kaldor JM, Grulich AE. How homosexual men believe they became infected with HIV: the role of risk-reduction behaviors. J Acquir Immune Defic Syndr 2007; 46:245-7. 
30. Parsons JT, Schrimshaw EW, Wolitski RJ, Halkitis PN, Purcell DW, Hoff CC, et al. Sexual harm reduction practices of HIV-seropositive gay and bisexual men: serosorting, strategic positioning, and withdrawal before ejaculation. AIDS 2005; 19:13-25.

31. Carballo-Diéguez A, Dowsett GW, Ventuneac A, Remien RH, Balan I, Dolezal C, et al. Cybercartography of popular internet sites used by New York City men who have sex with men interested in bareback sex. AIDS Educ Prev 2006; 18:475-89.

32. Fernández-Dávila P, Zaragoza Lorca K. Trust and sexual interaction: the significance of the Internet on the sex life and sexual risk behaviors of gay and bisexual men in Spain. Int J Sex Health 2011; 23:120-38.
33. Hart GJ, Elford J. Sexual risk behaviour of men who have sex with men: emerging patterns and new challenges. Curr Opin Infect Dis 2010; 23:39-44.

34. Gomez AM, Beougher SC, Chakravarty D, Neilands TB, Mandic CG, Darbes LA, et al. Relationship dynamics as predictors of broken agreements about outside sexual partners: implications for HIV prevention among gay couples. AIDS Behav 2012; 16:1584-8.

Submitted on 28/Jul/2013

Final version resubmitted on 18/Mar/2014

Approved on 25/Abr/2014 